\title{
Empirical Analysis Of The Impact Of Comprehensive Income On Basic Earnings Per Share For Spanish Companies Listed On Madrid Stock Exchange
}

Francisco Sousa Fernández PhD. University of Cantabria, Spain María Mercedes Carro Arana, PhD. University of Cantabria, Spain

\begin{abstract}
In this study we will empirically evaluate the overall impact, and by industries, of Basic Earnings per Share calculated according to Comprehensive Income against the same ratio determined in accordance with Net Income, for a sample of ninety-two Spanish groups listed on the Madrid Stock Exchange during 2004-2007, in agreement with the information contained in their Consolidated Financial Statements pursuant to IASB GAAP and industry classification adopted in this market.

In order to contrast the corresponding hypotheses, a set of non-parametric tools were used, as the data was far from normalcy. The results of our paper, which are ground-breaking at an international level, show a statistically significant impact of Basic Earnings per Share calculated according to Comprehensive Income against the same ratio determined pursuant to Net Income for the sample group in all of the years that were analyzed. On the other hand, when approaching the study by industries, we have observed quite uniform behavior between them in the sense that we found a remarkable impact on listed companies in all industries, which is why in general terms we are witnessing a phenomenon that affects the listed companies regardless of the nature of their business activities.

These evidences, apart from suggesting a new dimension in the fundamental analysis, of particular interest to analysts and investors, justifies the disclosure of Basic Earnings per Share determined according to Comprehensive Income, not only in the notes, but also in the main body of the Statement of Comprehensive Income.
\end{abstract}

Keywords: Basic Earnings per Share (Comprehensive Income), Basic Earnings per Share (Net Income), IAS 1, IAS 33, Spanish Listed Companies on the Madrid Stock Exchange

\section{INTRODUCTION}

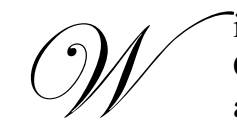

ith the revision in 2007 of IAS 1 of the IASB, which entered into force on $1^{\text {st }}$ January 2009 , Comprehensive Income, conceived as all-non-owners changes in equity [SFAC 6 (1985, par. 70) performance. ${ }^{1}$ and SFAS 130 (1997) of the FASB], is acquiring more importance as an indicator of business

Conversely, IAS 33 (2003) of the IASB regulates the determination and revelation of the Basic and Diluted Earnings per Share; in paragraph 73, the door is left open to companies so that they can disclose the impact of other figures of the Statement of Comprehensive Income incorporated by IAS 1 (2007), on the weighted average number of common shares in circulation.

From the related figures that make up this financial statement it is possible to emphasize its bottom line, Comprehensive Income, as it has been previously conceptualized, so it is determined according to the normative 
body of the IASB starting with Net Income-profit or loss-, to which the expenses and income that must be directly recognized in equity according to the corresponding regulations are added. This affects changes in fair value of available-for-sale financial instruments, those associated to the cash-flow hedges, certain foreign currency exchange differences or changes in fair value of property, plant and equipment or intangible assets if the companies decide on this evaluation criterion, meaning that Comprehensive Income is more closely related to the reality of the markets than traditional net income.

In agreement with the above-mentioned information, we set out to empirically evaluate the global impact and the impact by industries of the Basic Earnings per Share calculated according to Comprehensive Income against the same ratio determined in accordance with Net Income, basing our study on a sample of ninety-two Spanish groups listed on the Madrid Stock Exchange during 2004-2007; for this, we took the information contained in the Consolidated Financial Statements as reference.

To address this matter, besides the analysis of the corresponding descriptive statistics and of the results obtained from box plots, since data is outside of the normal range, we adopted a non-parametric set of tools as a contrast tool for the hypothesis formulated.

Our study, besides entering a field that has not yet been researched, is of particular interest since paragraph B102 of the Basis for Conclusions of the IAS 1 (2007) refers to the fact that, during the discussion period, the IASB received certain suggestions to include this regulation in the main body of the financial statements with other alternative measures to the traditional earnings per share.

This is because the classic Earnings per Share determined according to the traditional Net Income is not considered the most relevant indicator for financial analysts; therefore, as we do in our research, they propose other alternatives for its calculation, such as determining it in accordance with Comprehensive Income. This is something that the IASB does not rule out and can reconsider within the framework of the present project, Financial Statements Presentation, at the same time being integrated into the Memorandum of Understanding (MoU) which is being developed together with the FASB.

We can foresee that the Basic Earnings per Share calculated according to Comprehensive Income significantly impacts on the same ratio determined pursuant traditional Net Income for the sample set of Spanish companies listed on the Madrid Stock Exchange in each year between 2004-2007. When approaching the study by industries, quite uniform behavior is observed in the sense that a remarkable impact is found on listed companies in all industries, which is why in general terms this phenomenon can be said to affect the listed companies regardless of the nature of their business activities.

Besides suggesting a new tool for fundamental analysis, of particular interest to investors and analysts, the empirical evidence found justifies not only its inclusion in the notes of the Basic Earnings per Share determined according to Comprehensive Income, but also its revelation in a much more prominent and important way in the main body of the Statement of Comprehensive Income.

\section{RESEARCH DESIGN} of our study.

In accordance with the general approach that we have referred to, we would now like to specify the design

\subsection{Aim}

When reviewing the empirical accounting literature on Comprehensive Income from recent years, we observed that aside from a series of studies that were descriptive in nature (Luecke and Meeting, 1998; Bhamornsiri and Wiggins, 2001; Pandit et al., 2006, among others), some research was dedicated to capital market (Dhaliwal et al., 1999; O'Hanlon and Pope, 1999 and Hodder et al., 2006, among others), and some research concentrated on the study of the impact of the formats for their presentation on analysts and investors (Hirst and Hopkins, 1998; Maines and McDaniel, 2000; and Hunton et al., 2006). 
Nevertheless, no research has been conducted to empirically evaluate the impact of Basic Earnings per Share according to Comprehensive Income against the same ratio determined pursuant to Net Income, as we do in our study, which means we are pioneering research at an international level.

Our study is of particular interest since the Basis for Conclusions of the IAS 1 (2007) refer to the fact that, during the discussion period, the IASB received certain suggestions to include this regulation in the main body of the financial statements with other alternative measures to the traditional Earnings per Share. This is because the classic Earnings per Share determined according to the traditional Net Income is not considered the most relevant indicator for financial analysts; therefore, as we do in our research, they propose other alternatives for its calculation, such as determining it in accordance with Comprehensive Income.

On the other hand, it would also be possible to complement and extend our research to the impact of Comprehensive Income in other relevance ratios for the analysis such as the PER; however such extension exceeds the limits of this paper and its objective and therefore it can be investigated in later studies.

Also, still being conscious of the limitations for the analysis that could present any ratio in which the information from the annual accounts presented by the companies is taken as reference, due essentially to the accounting policies followed, the fact of considering Comprehensive Income, a much wider measurement of business performance than traditional net income, incorporates a new perspective for the analysis of the earnings of economic entities.

\section{$2.2 \quad$ Sample}

In order to carry out the corresponding empirical contrasts that will be explained later in detail, we have started with the list of all the companies listed on the Madrid Stock Exchange at $31^{\text {st }}$ December 2007, excluding foreign companies as well as Spanish companies that only present individual accounts, or which are not listed in certain years during the study period 2004-2007, those that adopted a closing date different than 31 December, and those that did not reveal Comprehensive Income or disclosed it in an unclear way; in the end, the result was a sample of ninety-two corporate groups.

For each one of the integral companies of the sample, we have taken the information necessary to carry out the investigation of its Consolidated Financial Statements for the years 2005, 2006, and 2007, available on the CNMV's (Comisión Nacional del Mercado de Valores, National Securities Market Commission) website ${ }^{2}$. Data from 2004 were also available as comparative information in the Consolidated Financial Statements for 2005.

We want to emphasize that the majority of corporate groups did not reveal Comprehensive Income in accordance with the rules of NIC 1 (2003), particularly those that chose to do so through the Statement of Changes in Equity, which means that we had to construct the Comprehensive Income variable starting from the integrated items, which were dispersed in this financial statement or through the notes.

On the other hand, the capitalization of the listed companies that are integrated in the sample at $31^{\text {st }}$ December 2007, the last year included in our study, rose to sixty percent of the total capitalization on the stock exchange of Madrid, and to ninety percent of the capitalization of all the Spanish companies listed at this date on that market, and thus we are faced with a high representativeness of the sample of the ninety-two groups considered in our study.

Also, it is necessary to incorporate the variable industry to contrast one of the hypotheses formulated. Table 1 shows a classification by industries of the corporate groups of the sample in accordance with the industrial classification used by the stock exchange of Madrid; a high representativeness of the corporate groups of our sample over the totals assigned to each sector can be observed. 
Table 1

Classification by industries of the Spanish corporate groups of the sample in accordance with industry classification of the Madrid Stock Exchange

\begin{tabular}{|c|c|c|c|c|}
\hline Industry & Code & $\begin{array}{l}\text { Descriptors of the sectors } \\
\text { associated to each industry }\end{array}$ & $\begin{array}{l}\text { Number } \\
\text { of sample } \\
\text { groups }\end{array}$ & $\begin{array}{l}\text { Percentage of sample } \\
\text { groups out of the } \\
\text { total listed companies } \\
\text { in each industry * }\end{array}$ \\
\hline Oil \& Energy & OIE & $\begin{array}{l}\text { Petroleum. Electricity and Gas. } \\
\text { Water and Others. Renewable Energies. }\end{array}$ & 9 & $82 \%$ \\
\hline Basic Materials & BSM & $\begin{array}{l}\text { Mineral, Metals and Transformation. } \\
\text { Manufacture and Assembly of Capital } \\
\text { Resources. Construction. Building Materials. } \\
\text { Chemical Industry. Engineering and Others. } \\
\text { Aerospace Industry. }\end{array}$ & 25 & $78 \%$ \\
\hline Consumer Goods & CSG & $\begin{array}{l}\text { Food and Beverages. Textile, Clothing and } \\
\text { Footwear. Paper and Graphic Arts. } \\
\text { Automotive. Pharmaceutical Products and } \\
\text { Biotechnology. Other Consumer Goods. }\end{array}$ & 22 & $82 \%$ \\
\hline Consumer Services & CSS & $\begin{array}{l}\text { Leisure, Tourism and the Hotel Industry. } \\
\text { Retail Commerce. Communication and } \\
\text { Publicity Means. Transport and } \\
\text { Distribution. Motorways and Car Parks. } \\
\text { Other Services. }\end{array}$ & 12 & $67 \%$ \\
\hline $\begin{array}{l}\text { Financials \& } \\
\text { Real Estate }\end{array}$ & FIR & $\begin{array}{l}\text { Banking. Insurance. Portfolio and Holding } \\
\text { Companies. Open-Ended Investment } \\
\text { Companies. Estate Agents and Others. } \\
\text { Investment Services. }\end{array}$ & 19 & $58 \%$ \\
\hline $\begin{array}{c}\text { Technology \& } \\
\text { Telecommunications }\end{array}$ & TET & $\begin{array}{l}\text { Telecommunications and Others. } \\
\text { Electronics and Software. }\end{array}$ & 5 & $83 \%$ \\
\hline
\end{tabular}

* In accordance with the criteria followed for the homogenization of the sample, foreign corporations and Spanish corporations that only present individual accounts have been excluded in each sector for the calculation of the corresponding percentage.

Source: prepared from the database and from data obtained from the website of the Madrid Stock Exchange.

Finally, it is important to specify that all the listed companies of the European Union are obliged to formulate their Consolidated Financial Statements in accordance with the IFRS of the IASB from $1^{\text {st }}$ January 2005. This means that our study, circumscribed to Spanish companies listed on the Madrid Stock Exchange, not only represents a first step in the area studied at an international level, but also invites future research fields to expand in order to include companies listed on all European Stock Markets as well as the rest of the important securities markets at the international level.

\subsection{Hypotheses and Testing Methods}

Before describing the formulation of the hypotheses and the justification of the tools that will be used to carry out its contrast, it is necessary to explain the variable of the Basic Earnings per Share determined according to Net Income for each year $t$, which is determined in consideration of IAS regulations (2003), which obviously coincides with that disclosed in the Consolidated Financial Statements of the listed companies of the sample when such regulations apply.

Basic Earnings per Share $(t)=$ (Net Income) [BEPS-NI]
Net Income attributable to ordinary equity holders of the parent entity $(t)$

Weighted average number of ordinary shares outstanding $(t)$ 
Likewise, we also needed to define the new variable included in our study of the Basic Earnings per Share calculated according to Comprehensive Income.

Comprehensive Income attributable to ordinary equity holders of the parent entity $(t)$ Basic Earnings per Share $(t)=$

(Comprehensive Income) [BEPS-CI] Weighted average number of ordinary shares outstanding $(t)$

In both mathematical expressions Net Income and Comprehensive Income have been determined in consideration of the continuing operations, which is why discontinued operations are excluded since they appear in a very reduced number of corporate groups. Also, we have to consider that both the numerator and the denominator, according to the cases, have been adjusted by the corporate groups to comply with the corresponding rules established in IAS 33. On the other hand, we have not considered the Diluted Earnings per Share because the great majority of the groups have only presented the Basic Earnings per Share.

Once the variables have been defined, and as stated at the beginning of our paper, we firstly wish to evaluate the impact of Basic Earnings per Share calculated according to Comprehensive Income on the same ratio determined pursuant to Net Income for the period 2004-2007, taking as reference the aforementioned sampling, to which purpose we formulated the following null hypothesis along with its corresponding alternative hypothesis:

$\mathbf{H}_{\mathbf{0}} \mathbf{1}$ Basic Earnings per Share determined according to Comprehensive Income (BEPS-CI) does not show a significant impact regarding Basic Earnings per Share calculated in accordance with Net Income (BEPSNI) for each of the years in the period 2004-2007, both determined pursuant to IASB GAAP, for the Spanish corporate groups listed on the Madrid Stock Exchange.

$$
\begin{aligned}
& \theta_{B E P S-C I 2004}=\theta_{B E P S-N I 2004} \\
& \theta_{B E P S-C I 2005}=\theta_{B E P S-N I 2005} \\
& \theta_{B E P S-C I 2006}=\theta_{B E P S-N I 2006} \\
& \theta_{B E P S-C I 2007}=\theta_{B E P S-N I 2007}
\end{aligned}
$$

$\mathbf{H}_{\mathbf{1}} \mathbf{1}$ Alternative hypothesis: $\theta_{B E P S-C I} \neq \theta_{B E P S-N I}$ for at least a year $k$.

In order to test this hypothesis and its corresponding alternative hypothesis, it might be pertinent to compare the means between Basic Earnings per Share determined according to Comprehensive Income and Net Income for the period 2004-2007 with the parametric tool Student's T Test for paired samples.

However, pursuant to the Kolmogorov-Smirnov One-Sample Test, we reject the null hypothesis of normality for the variables comprising the difference between both types of Basic Earnings per Share in each of the years studied. Thus, as the data does not fit in with a normal distribution, we must use for comparison purposes, the alternative non-parametric tool Wilcoxon Signed-Rank Test, with a confidence level of $95 \%$, and therefore a significance value of $p<0.05$.

The Wilcoxon Signed-Rank Test contrasts the null hypothesis that the medians of two related variables are equal, which applied to the specific scope of our investigation will allow us to prove whether Basic Earnings per Share determined according to Comprehensive Income differs significantly from the same ratio calculated in accordance with Net Income, both determined pursuant to IASB GAAP for the period 2004-2007 for the set of Spanish groups listed on the Madrid Stock Exchange.

Moreover, as was stated, we wish to provide empirical proof regarding whether there are differences between industries with respect to the impact of Basic Earnings per Share calculated according to Comprehensive 
Income and the same ratio determined pursuant and Net Income for the aforementioned sampling and period. To do this we formulated this null hypothesis along with its alternative hypothesis:

$\mathbf{H}_{\mathbf{0}} 2$ Among the different Industries in which the Spanish corporate groups listed on the Madrid Stock Exchange operate, there are no significant differences for each of the years in the period 2004-2007 regarding the impact of Basic Earnings per Share determined according to Comprehensive Income (BEPS-CI) and the same ratio calculated in accordance with Net Income (BEPS-NI), both disclosed pursuant to IASB GAAP.

$$
\begin{aligned}
& \theta_{\text {OIE-2004 }}=\theta_{B S M-2004}=\theta_{C S G-2004}=\theta_{C S S-2004}=\theta_{F I R-2004}=\theta_{T E T-2004} \\
& \theta_{\text {OIE-2005 }}=\theta_{B S M-2005}=\theta_{C S G-2005}=\theta_{C S S-2005}=\theta_{F I R-2005}=\theta_{T E T-2005} \\
& \theta_{\text {OIE-2006 }}=\theta_{B S M-2006}=\theta_{C S G-2006}=\theta_{C S S-2006}=\theta_{F I R-2006}=\theta_{T E T-2006} \\
& \theta_{\text {OIE-2007 }}=\theta_{B S M-2007}=\theta_{C S G-2007}=\theta_{C S S-2007}=\theta_{F I R-2007}=\theta_{T E T-2007}
\end{aligned}
$$

$\mathbf{H}_{1} 2$ Alternative hypothesis: $\theta_{i, k} \neq \theta_{j, k}$ for at least a pair of industries $i$ and $j$ in a year $k$.

The impact of Basic Earnings per Share determined according to Comprehensive Income and the same ratio calculated pursuant to Net Income in each of the years for each corporate group included in its corresponding sector is determined by the expression Diff. $=($ BEPS-CI - BEPS-NI $)$, and as both ratios are already obviously relative values this difference expresses the relative discrepancy in each case.

In order to test this hypothesis and its corresponding alternative hypothesis, given that we have a betweensubjects factor in the sense that not all of the subjects or corporate groups undergo the same treatments, as evidently each one is associated to its corresponding sector, it might be suitable to use a One Way ANOVA model, which allows us to prove whether there are significant differences between multiple groups. ${ }^{3}$

However, having applied the Kolmogorov-Smirnov One-Sample Test, we rejected the null hypothesis of normality for the variables object of contrast. Therefore, as the data does not fit in with normal distribution, a necessary assumption in order to apply ANOVA models, we must use the alternative non-parametric Kruskal-Wallis test for comparison, also known as the Kruskal-Wallis one-way analysis of variance by ranks (Siegel and Castellan, 1988). This test allows us to compare whether a set of $k$ independent samples come from the same population, that is, whether a factor, in our case the sector factor, which subdivides the population of origin, significantly affects its central value.

But this test assumes that the variables being the subject of contrast are distributed similarly between the different groups, in this case between the different industries, and pursuant to the study of the corresponding box plots we are far from this assumption, because we have a large number of extreme values and outliers distributed in quite a heterogeneous manner between the different industries and years.

Therefore, it is necessary to validate the results obtained with the Median Test, which is known not to need this requirement. But in turn, its weakness is that it was not designed to take into account the distance from the median, which the Kruskal-Wallis Test does.

If these two a priori tests show significant differences between the diverse industries, working with a confidence level of 95\%, and thus a significance level of $p<0,05$, we will have to carry out the corresponding post hoc tests, and thus find in which pairs of industries and in which specific years do the stated differences truly exist.

To this purpose the Mann-Whitney U Test should be suitable. This allows us to contrast the null hypothesis that two independent samples come from the same population. However, this test also assumes that the variables object of contrast have a similar distribution between the two groups compared, in our case between those corresponding to the different pairs of industries. However our data is far from fulfilling this requirement for the same reasons previously explained regarding the $a$ priori tests. 
Thus we are going to use the Kolmogorov-Smirnov Two-Sample Test in order to validate the assumption of similar distributions, which contrary to the Mann-Whitney U Test does not assume this condition, which confers flexibility but at the same time makes it very sensitive to the differences both in location and scale.

\section{RESEARCH RESULTS}

Once the sample group has been defined, the hypotheses designed and the comparison methods justified, we now intend to show and analyze the results of our research in the following sections.

\subsection{Overall Impact}

We proceed to contrast the first hypothesis formulated and its corresponding alternative hypothesis, after showing in Graphic 1 the profile of the Basic Earnings per Share means calculated according to Net Income and Comprehensive Income, and in Table 2 the descriptive statistics of both ratios for the sample group in the four years researched.

\section{Graphic 1}

Profile of the average values of Basic Earnings per Share calculated according to Net Income (BEPS-NI) and Basic Earnings per Share determined in accordance with Comprehensive Income (BEPS-CI), for the Spanish companies listed on the Madrid Stock Exchange during 2004-2007

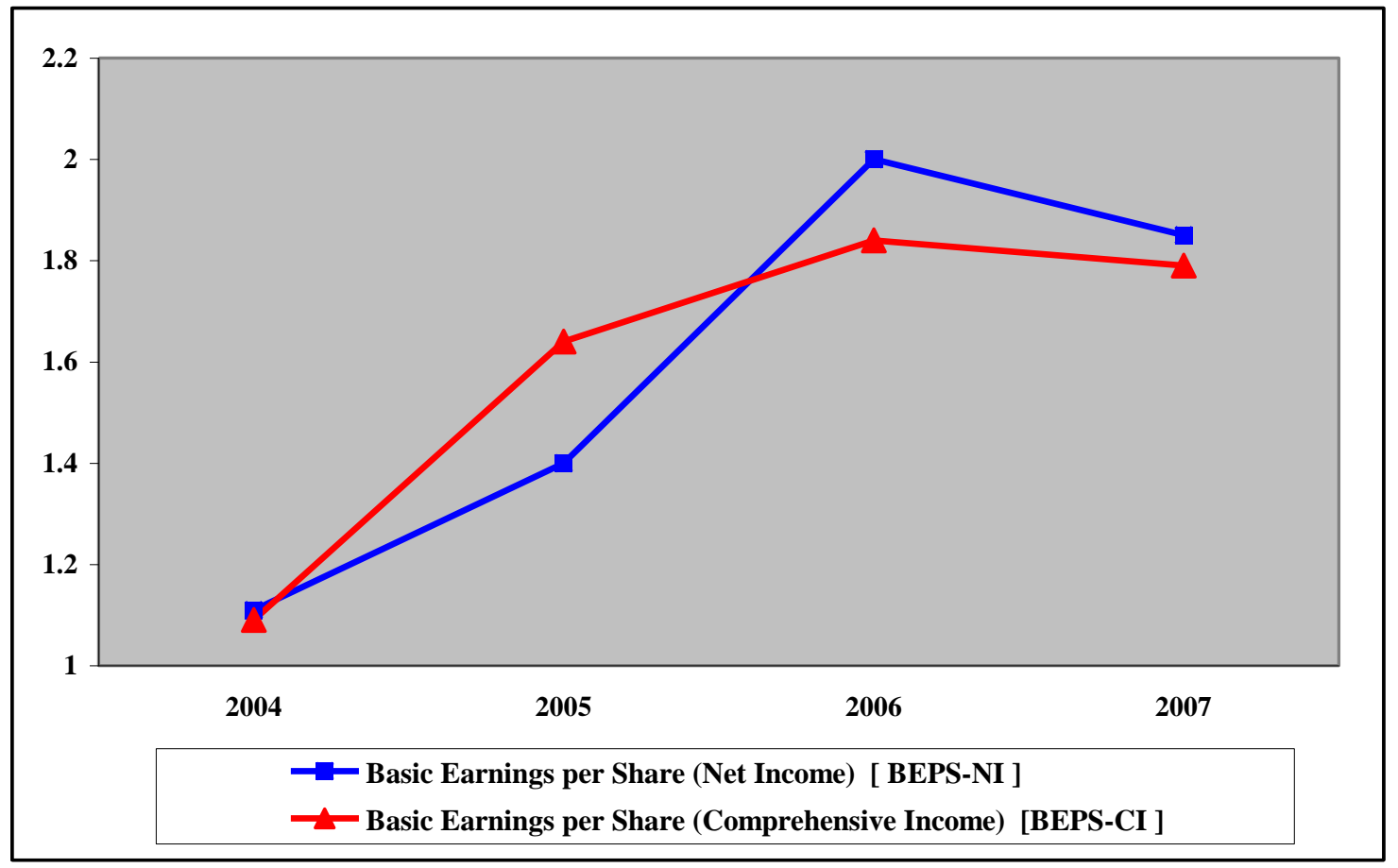

Source: authors' calculations based on the Database and SPSS v.17.

The discrepancies between both ratios, particularly noticeable in 2005 and 2006, are obviously caused by the new elements that add Comprehensive, among which we should emphasize the marked impact of the foreign currency exchange differences item in the conversion of the assets and liabilities of the foreign subsidiaries caused by the appreciations/depreciations of the euro against the U.S. dollar, distantly followed by the impact of the changes in the fair value of the financial assets classified as available-for-sale, and with hardly any effect on the derived item and hedging transactions and on the rest of the items such as the changes in the fair value of tangible and intangible assets. 
Table 2

Descriptive statistics of Basic Earnings per Share calculated according to

Net Income (BEPS-NI) and Basic Earnings per Share determined in accordance with Comprehensive Income (BEPS-CI), for Spanish companies listed on the Madrid Stock Exchange during 2004-2007

\begin{tabular}{|c|c|c|c|c|c|c|c|c|}
\hline Variable & N & Mean & $\begin{array}{c}\text { Standard } \\
\text { Deviation }\end{array}$ & Minimum & $\begin{array}{c}\text { First } \\
\text { Quartile }\end{array}$ & Median & $\begin{array}{c}\text { Third } \\
\text { Quartile }\end{array}$ & Maximum \\
\hline BEPS-NI 2004 & 92 & 1.11 & 1.10 & -0.16 & 0.31 & 0.76 & 1.42 & 4.57 \\
\hline BEPS-CI 2004 & 92 & 1.09 & 1.10 & -0.28 & 0.30 & 0.74 & 1.45 & 4.41 \\
\hline BEPS-NI 2005 & 92 & 1.40 & 1.62 & -0.69 & 0.45 & 0.87 & 1.70 & 7.77 \\
\hline BEPS-CI 2005 & 92 & 1.64 & 2.26 & -0.87 & 0.46 & 1.05 & 1.95 & 14.55 \\
\hline BEPS-NI 2006 & 92 & 2.00 & 3.62 & -0.80 & 0.38 & 1.05 & 1.87 & 22.06 \\
\hline BEPS-CI 2006 & 92 & 1.84 & 3.55 & -2.31 & 0.24 & 0.96 & 1.59 & 22.19 \\
\hline BEPS-NI 2007 & 92 & 1.85 & 3.50 & -2.87 & 0.36 & 0.98 & 1.86 & 25.55 \\
\hline BEPS-CI 2007 & 92 & 1.79 & 3.28 & -2.92 & 0.34 & 0.95 & 1.97 & 23.39 \\
\hline
\end{tabular}

Source: authors' calculations based on the database and SPSS v.17.

Table 3

Ranks of Wilcoxon Signed-Rank Test for Comparison of Basic Earnings per Share calculated in accordance with Net Income (BEPS-NI) and Basic Earnings per Share determined in accordance with Comprehensive Income (BEPS-CI), for Spanish companies listed on the Madrid Stock Exchange during 2004-2007

\begin{tabular}{|c|c|c|c|}
\hline & $\mathbf{N}$ & Mean Ranks & Sum of Ranks \\
\hline Negative Ranks & 23 (a) & 36.52 & 840.00 \\
\hline $\begin{array}{ll}\text { BEPS-NI2004 } & \text { Positive Ranks }\end{array}$ & $51(\mathrm{~b})$ & 37.94 & $1,935.00$ \\
\hline BEPS-CI2004 $\quad$ Ties & $18(\mathrm{c})$ & & \\
\hline Total & 92 & & \\
\hline Negative Ranks & $61(\mathrm{~d})$ & 40.70 & $2,483.00$ \\
\hline Positive Ranks & $16(\mathrm{e})$ & 32.50 & 520.00 \\
\hline BEPS-CI2005 & 15 (f) & & \\
\hline Total & 92 & & \\
\hline Negative Ranks & $27(\mathrm{~g})$ & 41.26 & $1,114.00$ \\
\hline BEPS-NI2006 & $54(\mathrm{~h})$ & 40.87 & $2,207.00$ \\
\hline BEPS-CI2006 & 11 (i) & & \\
\hline Total & 92 & & \\
\hline Positive Ranks & $21(\mathrm{j})$ & 43.48 & 913.00 \\
\hline Negative Ranks & $59(\mathrm{k})$ & 39.44 & $2,327.00$ \\
\hline BEPS-CI2007 & $12(1)$ & & \\
\hline Total & 92 & & \\
\hline
\end{tabular}

a BEPS-NI2004 < BEPS-CI2004; b BEPS-NI2004 > BEPS-CI2004; c BEPS-NI2004 = BEPS-CI2004; d BEPS-NI2005 < BEPS-CI2005

e BEPS-NI2005 > BEPS-CI2005; f BEPS-NI2005 = BEPS-CI2005; g BEPS-NI2006 < BEPS-CI2006; h BEPS-NI2006 > BEPS-CI2006

i BEPS-NI2006 = BEPS-CI2006; j BEPS-NI2007 < BEPS-CI2007; k BEPS-NI2007 > BEPS-CI2007; 1 BEPS-NI2007 = BEPS-CI2007

Source: authors' calculations, based on the database and SPSS v.17.0.

The discrepancies between both ratios detected by the previous descriptive statistics translates into remarkable differences between ranks when carrying out the Wilcoxon Signed-Rank Test, as shown in Table 3, which leads to statistically significant differences for the four years studied with $p<0.05$ as shown in Table 4 , which leads us to reject the null hypothesis $\mathrm{H}_{\mathrm{o}} 1$, and consequently to accept its alternative hypothesis $\mathrm{H}_{1} 1$. 
Table 4

Contrast statistics for the Wilcoxon Signed-Rank Test

for Comparison of Basic Earnings per Share calculated according to Net Income (BEPS-NI) and the Basic Earnings per Share determined in accordance with Comprehensive Income (BEPS-CI), for Spanish companies listed on the Madrid Stock Exchange during 2004-2007

\begin{tabular}{|c|c|c|c|c|}
\hline & $\begin{array}{c}\text { BEPS-NI2004 } \\
\text { BEPS-CI2004 }\end{array}$ & $\begin{array}{c}\text { BEPS-NI2005 } \\
\text { BEPS-CI2005 }\end{array}$ & $\begin{array}{c}\text { BEPS-NI2006 } \\
\text { BEPS-CI2006 }\end{array}$ & $\begin{array}{c}\text { BEPS-NI2007 } \\
\text { BEPS-CI2007 }\end{array}$ \\
\hline $\mathbf{Z}$ & $-2.950(\mathrm{a})$ & $-4.984(\mathrm{~b})$ & $-2.573(\mathrm{a})$ & $-3.391(\mathrm{a})$ \\
\hline Asymp. Sig. (2-tailed) & 0.003 & 0.000 & 0.010 & 0.000 \\
\hline
\end{tabular}

a. Based on negative ranks.

b. Based on positive ranks.

Source: authors' calculations, based on the database and SPSS v.17.0.

The empirical evidence found allows to state that for the group of Spanish companies listed on the Madrid Stock Exchange in each year during the period 2004-2007, the Basic Earnings per Share determined in accordance with Comprehensive Income impacts in a statistically significant way on the Basic Earnings per Share determined in accordance with Net Income, both disclosed according to IAS 1 of the IASB.

The previous information shows that, within the framework of the analysis of the Basic Earnings per Share, the higher informative content of Comprehensive Income compared to Net Income is motivated by the stronger connection of the former with the reality of the markets, which opens the door to a new dimension of fundamental analysis, particularly for analysts and investors.

Likewise this represents a contribution to the debate generated within the Presentation of Financial Statements project, jointly developed by the IASB and the FASB, given that, based on the statistical evidence contributed, the inclusion in the notes of the Basic Earnings per Share determined according to Comprehensive Income is not only justified, but also its revelation in the main body of the Statement of Comprehensive Income is included in a much more prominent or important way.

\subsection{Impact on Industries}

Once the global impact is analyzed, we wish to study the effects that are specific to industries, which means that we start by collecting the profile of the means in Graphics 2 and 3 and the descriptive statistics in Tables 5 and 6.

We can observe that the Basic Earnings per Share determined according to Comprehensive Income against the Basic Earnings per Share calculated in accordance with Net Income, greatly impacts the sample set, as shown in Graphic 1, particularly for the years 2005 and 2006, with a discrepancy of 0.24 and -0.16 respectively, and, to a lesser extent, the years 2004 and 2007, in which the differences are much less marked.

When distinguishing this impact by industries, the Oil \& Energy and Financial \& Real Estate industries are observed to present more variable behavior, also having a positive impact for the number of years studied, at a great distance from the Technology and Telecommunications industry, with a slight positive effect; whereas the Basic Materials, Consumer Goods, and Consumer Services industries register on average a negative impact for the four years studied.

At the same time, we wanted to approach the impact by industries from another perspective, basing our research on the analysis of the corresponding extreme values and outliers through the methodology of box plots, as shown in Table 7.

A remarkable number of listed companies, around $30 \%$ of the sample total, are found to present extreme values or outliers in one or more of the years studied, in some cases with a discrepancy level that we can only describe as spectacular, which indicates a marked effect in specific listed companies of all industries of the Basic 
Earnings per Share calculated according to Comprehensive Income against the same ratio determined pursuant to Net Income.

\section{Graphic 2}

Profile of the means of the difference between Basic Earnings per Share calculated according to Comprehensive Income (BEPS-CI) and Basic Earnings per Share determined pursuant to

Net Income (BEPS-NI), for each of the years in the period 2004-2007, by industries, for Spanish groups listed on the Madrid Stock Exchange

[Differences calculated through the expression: Diff. = (BEPS-CI - BEPS-NI $)]$

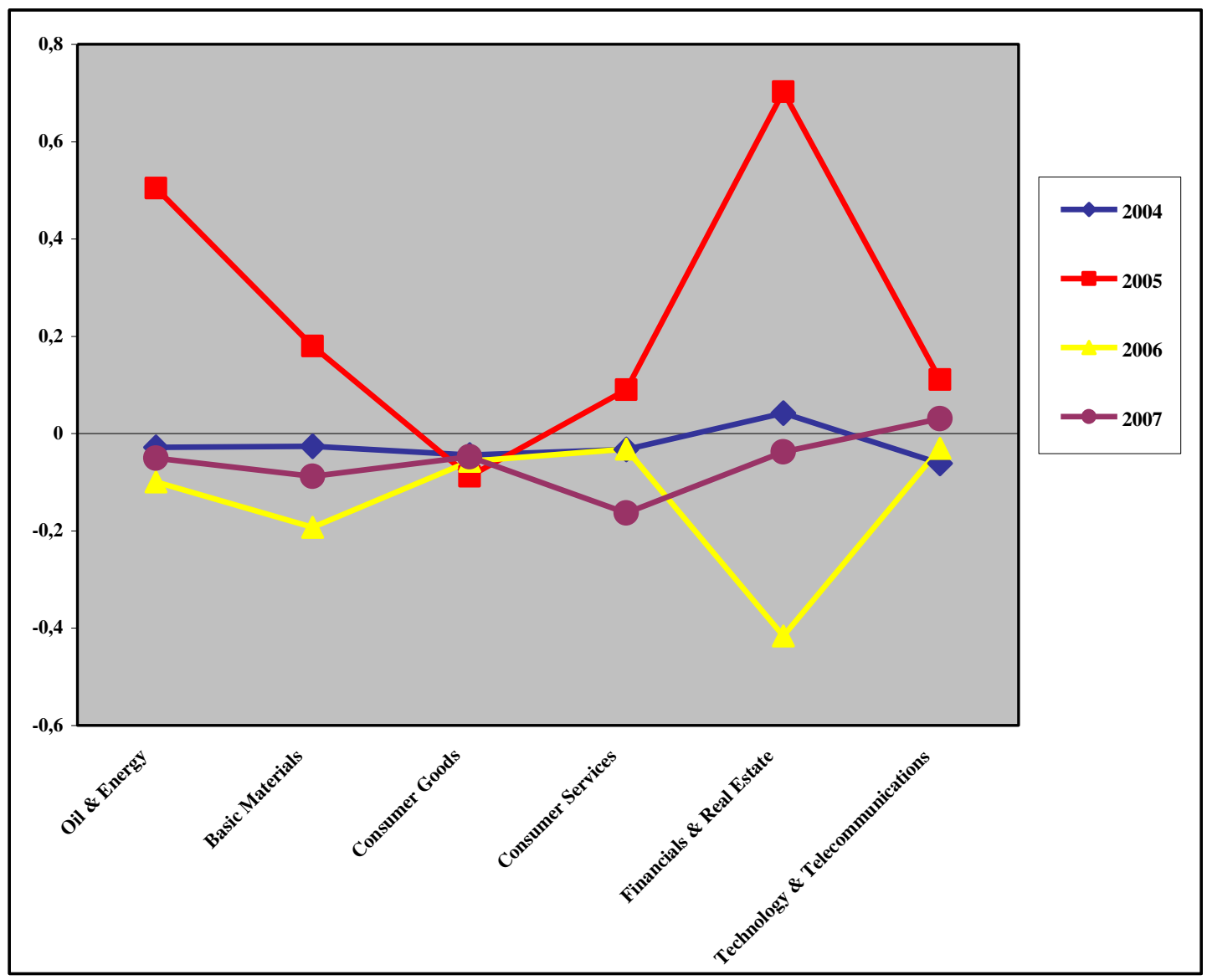

Source: authors' calculations, based on the database and SPSS v.17.0.

In any case, with the corresponding non-parametric tools and given that they are based on ranks and, therefore, immune to extreme observations, we will later be able to better discern whether the differences found among industries in this first approximation by analysis of the descriptive statistics are significant or not.

Proceeding to the analysis of the corresponding comparisons, Table 8 shows in the first place the mean ranks of the Kruskal-Wallis Test by industries regarding the difference between Basic Earnings per Share calculated according to Comprehensive Income and Basic Earnings per Share determined pursuant to Net Income.

We find that in general mean ranks do not differ greatly between the different industries, except for the Financials \& Real Estate industry in 2004 and the Oil \& Energy sector in 2005, without forgetting the Technology \& Telecommunications sector in 2007. 


\section{Graphic 3}

Profile of the means of the difference between Basic Earnings per Share calculated according to Comprehensive Income (BEPS-CI) and Basic Earnings per Share determined pursuant to

Net Income (BEPS-NI), by industries, for Spanish groups listed on the Madrid Stock Exchange

[Differences calculated through the expression: Diff. $=($ BEPS-CI - BEPS-NI $)]$

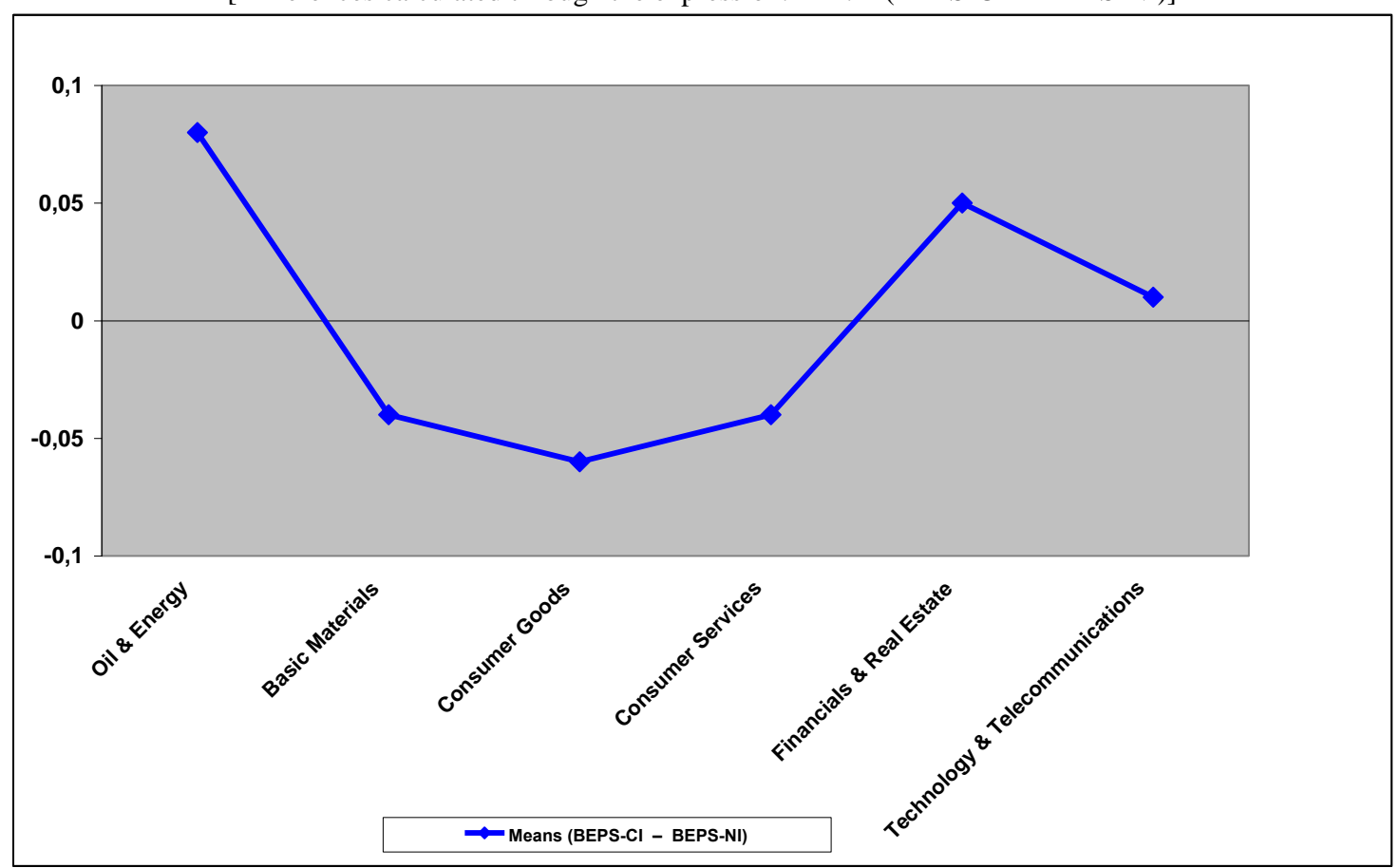

Source: authors' calculations, based on the database and SPSS v.17.0.

Table 5

Descriptive statistics of the difference between Basic Earnings per Share calculated according to Comprehensive Income (BEPS-CI) and Basic Earnings per Share determined pursuant to

Net Income (BEPS-NI) for each of the years in the period 2004-2007,

for Spanish groups listed on the Madrid Stock Exchange

[Differences calculated through the expression: Diff. = (BEPS-CI - BEPS-NI $)]$

\begin{tabular}{|c|c|c|c|c|c|c|c|c|}
\hline Variable & N & Mean & $\begin{array}{c}\text { Standard } \\
\text { Deviation }\end{array}$ & Minimum & $\begin{array}{c}\text { First } \\
\text { Quartile }\end{array}$ & Median & $\begin{array}{c}\text { Third } \\
\text { Quartile }\end{array}$ & Maximum \\
\hline (BEPS-CI2004 - BEPS-NI2004) & 92 & -0.02 & 0.14 & -0.57 & -0.05 & 0.00 & 0.00 & 0.78 \\
\hline (BEPS-CI2005 - BEPS-NI2005) & 92 & 0.24 & 1.00 & -3.21 & 0.00 & 0.03 & 0.20 & 7.78 \\
\hline (BEPS-CI2006 - BEPS-NI2006) & 92 & -0.16 & 1.08 & -9.45 & -0.13 & -0.01 & 0.01 & 1.11 \\
\hline (BEPS-CI2007 - BEPS-NI2007) & 92 & -0.06 & 0.70 & -2.38 & -0.15 & -0.02 & 0.00 & 4.07 \\
\hline
\end{tabular}

Source: authors' calculations, based on the database and SPSS v.17.0.

All of these facts, as shown by Table 9, lead to $p<0.05$ and therefore to significant differences only for the year 2004.

Similarly, by carrying out the Median Test to reinforce the results of the previous Kruskal-Wallis Test for the reasons that we have given, we find statistically significant differences only for 2004, which we do not specify in the corresponding Tables for brevity reasons. 
Consequently, in accordance with the results that fully coincide in both tests, we reject the null hypothesis $\mathrm{H}_{\mathrm{o}} 2$, and we accept its alternative hypothesis $\mathrm{H}_{1} 2$, given that there are significant differences between industries regarding the difference between Basic Earnings per Share calculated according to Comprehensive Income and Basic Earnings per

Table 6

Impact by industries of the means of the difference between Basic Earnings per Share calculated according to Comprehensive Income (BEPS-CI) and Basic Earnings per Share determined pursuant to Net Income (BEPS-NI) for each of the years in the period 2004-2007, for Spanish groups listed on the Madrid Stock Exchange [Differences calculated through the expression: Diff. = (BEPS-CI - BEPS-NI)]

\begin{tabular}{|c|c|c|c|c|c|c|}
\hline INDUSTRY & CODE & $\begin{array}{c}\text { (BEPS-CI2004 } \\
- \text { BEPS-NI2004) }\end{array}$ & $\begin{array}{c}\text { (BEPS-CI2005 } \\
- \text { BEPS-NI2005) }\end{array}$ & $\begin{array}{c}\text { (BEPS-CI2006 } \\
- \text { BEPS-NI2006) }\end{array}$ & $\begin{array}{c}\text { (BEPS-CI2007 } \\
- \text { BEPS-NI2007) }\end{array}$ & $\begin{array}{c}\text { Mean } \\
\text { 1999-2004 }\end{array}$ \\
\hline Oil \& Energy & OIE & -0.02 & 0.50 & -0.10 & -0.05 & 0,08 \\
\hline Basic Materials & BSM & -0.03 & 0.18 & -0.20 & -0.09 & -0.04 \\
\hline Consumer Goods & CSG & -0.04 & -0.09 & -0.06 & -0.05 & -0.06 \\
\hline $\begin{array}{c}\text { Consumer Services } \\
\text { Financials \& }\end{array}$ & CSS & -0.03 & 0.08 & -0.04 & -0.16 & -0.04 \\
\hline $\begin{array}{c}\text { Real Estate } \\
\text { Technology \& }\end{array}$ & TET & -0.06 & 0.04 & 0.70 & -0.50 & -0.04 \\
\hline TIR & -0.02 & 0.24 & -0.11 & 0.03 & 0.01 \\
\hline
\end{tabular}

Source: authors' calculations, based on the database and SPSS v.17.0.

Share determined pursuant to Net Income, even if this is true for only one year of the period 2004-2007.

Once we know, thanks to these a priori comparisons, that there are significant differences between industries regarding the said discrepancy, we carry out the Mann-Whitney U Test as a post hoc test to determine for which pairs of industries the differences arose for said year. The results are shown in Tables 10 and 11, where due to the fifteen possible comparisons per pairs for each year between the six industries considered and for brevity purposes those with $p \geq 0.05$, obviously not significant, have been omitted.

On the other hand, when the Kolmogorov-Smirnov Two Sample Test was carried out to reinforce the results of the previous Mann-Whitney U Test for the reasons already explained, we find statistically significant differences in the year 2004 for the Financials \& Real State compared to the Oil \& Gas, Consumer Goods and Technology \& Telecommunications, which we do not specify in the corresponding Tables for brevity reasons. Thus the results are similar regarding the Mann-Whitney U Test.

If we keep in mind that for each year we have fifteen possible combinations of pairs of industries to compare, which means a total of sixty comparisons for the years studied, the results of both tests greatly coincide in the sense that they find significant differences in a small number of the said comparisons.

As corollary of all the comparisons made in this section, we have empirical evidence to affirm that considering all the years included in the study, 2004 is the only one when there are significant differences in industries regarding Basic Earnings per Share calculated according to Comprehensive Income and Basic Earnings per Share determined pursuant to Net Income, which led us to reject the null hypothesis $\mathrm{H}_{\mathrm{o}} 2$, and consequently to accept the alternative hypothesis $\mathrm{H}_{1} 2$, but quite lightly, given that significant differences were only registered in a very small number of the sixty possible combinations of pairs of industries to be compared. 
Table 7

Spanish corporate groups listed on the Madrid Stock Exchange with extreme values (*) or outliers $(\circ)$ in each sector with respect to the differential between the Basic Earnings per Share

calculated according to Comprehensive Income (BEPS-CI) and the same ratio determined in accordance with Net Income (BEPS-NI), for the years during the period 2004-2007 ${ }^{4}$

\begin{tabular}{|c|c|c|c|c|c|c|c|}
\hline INDUSTRY & $\begin{array}{l}\text { Percentage } \\
\text { of groups of } \\
\text { the sector } \\
\text { included in } \\
\text { the sample }\end{array}$ & GROUP & 2004 & 2005 & 2006 & 2007 & $\begin{array}{c}\text { Mean } \\
\text { 2004-2007 }\end{array}$ \\
\hline \multirow{2}{*}{ Oil \& Energy } & \multirow[t]{2}{*}{$22 \%$} & Repsol & $-0.31 *$ & 0.87 & $-0.86 \circ$ & $-0.87 *$ & -0.29 \\
\hline & & Unión Fenosa & $0.27 *$ & 1.11 & 0.62 & 0.26 & 0.57 \\
\hline \multirow{8}{*}{ Basic Materials } & \multirow[t]{8}{*}{$32 \%$} & Abengoa & $-0.23 \circ$ & 0.45 & -1.00 & $1.44 \circ$ & 0.17 \\
\hline & & Acciona & -0.02 & $2.67 *$ & 0.13 & $-2.38 *$ & 0.10 \\
\hline & & $\begin{array}{c}\text { Actividades de } \\
\text { Constucción y Servicios }\end{array}$ & -0.13 & 0.26 & -0.24 & $2.01 *$ & 0.48 \\
\hline & & Befesa Medio Ambiente & -0.03 & -0.42 & $-3.17 *$ & $4.07 *$ & 0.87 \\
\hline & & Cementos Portland & $-0.57 *$ & 0.65 & -0.48 & -0.86 & -0.32 \\
\hline & & $\begin{array}{c}\text { Construcciones y } \\
\text { Auxiliar de Ferrocarriles }\end{array}$ & 0.02 & 0.07 & $1.11 \circ$ & -2.16 ○ & -0.24 \\
\hline & & Grupo Ferrovial & 0.00 & -0.40 & $0.91 \circ$ & $-2.33 *$ & -0.46 \\
\hline & & Sacyr Vallehermoso & $0.78 *$ & -0.25 & -0.56 & -0.44 & -0.12 \\
\hline \multirow{5}{*}{ Consumer Goods } & \multirow{5}{*}{$23 \%$} & Altadis & $-0.16 \circ$ & $0.43 *$ & $-0.38 \circ$ & $-0.44 *$ & -0.14 \\
\hline & & Ebro Puleva & $-0.15 \circ$ & 0.06 & -0.11 & -0.09 & -0.07 \\
\hline & & $\begin{array}{c}\text { Grupo Empresarial } \\
\text { Ence }\end{array}$ & $-0.16 \circ$ & $-3.21 *$ & -0.14 & $-0.33 *$ & -0.96 \\
\hline & & Iberpapel Gestión & -0.05 & $0.17 \circ$ & -0.19 & -0.08 & -0.04 \\
\hline & & Viscofan & -0.05 & $0.19 \circ$ & -0.03 & 0.02 & 0.03 \\
\hline \multirow{3}{*}{ Consumer Services } & \multirow[t]{3}{*}{$25 \%$} & Abertis Infraestructuras & $0.09 *$ & 0.08 & $0.28 \circ$ & 0.12 & 0.14 \\
\hline & & $\begin{array}{c}\text { Compañía de } \\
\text { Distribución Integral } \\
\text { Logista }\end{array}$ & $-0.15 *$ & 0.04 & $0.43 \circ$ & $-0.74 \circ$ & -0.11 \\
\hline & & Sol Meliá & $-0.23 *$ & $0.42 \circ$ & -0.41 & -0.51 & -0.18 \\
\hline \multirow{7}{*}{$\begin{array}{l}\text { Financials \& } \\
\text { Real Estate }\end{array}$} & \multirow[t]{7}{*}{$37 \%$} & Banco de Valencia & $\mathbf{0 . 0 8}$ & $1.27 *$ & -0.13 & -0.05 & 0.29 \\
\hline & & Banco Pastor & -0.02 & 0.08 & $0.56 *$ & 0.19 & 0.20 \\
\hline & & Bankinter & $0.47 *$ & $\mathbf{0 . 0 2}$ & -0.1 & -0.15 & 0.06 \\
\hline & & $\begin{array}{c}\text { Corporación } \\
\text { Financiera Alba }\end{array}$ & 0.07 & $7.78 *$ & $9.45 *$ & $1.19 *$ & 4.62 \\
\hline & & $\begin{array}{l}\text { Grupo Catalana } \\
\text { Occidente }\end{array}$ & 0.00 & $3.30 *$ & $0.29 \circ$ & -0.32 & 0.82 \\
\hline & & Inmobiliaria Colonial & $-0.28 *$ & 0.16 & $0.86 *$ & 0.02 & 0.19 \\
\hline & & Metrovacesa & $\mathbf{0 . 0 3}$ & -0.01 & $0.44 \circ$ & $-0.39 \circ$ & 0.02 \\
\hline \multirow{2}{*}{$\begin{array}{c}\text { Technology \& } \\
\text { Telecommunications }\end{array}$} & \multirow{2}{*}{$40 \%$} & Amper & 0.00 & $\mathbf{0 . 3 3}$ & $-0.15 \circ$ & $0.29 *$ & 0.12 \\
\hline & & Telefónica & -0.10 & 0.40 & 0.02 & $-0.16 *$ & 0.04 \\
\hline
\end{tabular}

Source: authors' calculations, based on the database and SPSS v.17.0. 
Table 8

Mean Ranks of Kruskal-Wallis Test for comparison of Basic Earnings per Share calculated according to Comprehensive Income (BEPS-CI) and Basic Earnings per Share determined pursuant to Net Income (BEPS-NI), by industries, for each of the years in the period 2004-2007 for Spanish groups listed on the Madrid Stock Exchange

\begin{tabular}{|c|c|c|c|c|c|c|}
\hline \multirow[b]{2}{*}{ INDUSTRY } & \multirow[b]{2}{*}{ CODE } & \multirow[b]{2}{*}{$\mathbf{N}$} & \multicolumn{4}{|c|}{ Mean Ranks } \\
\hline & & & $\begin{array}{r}\text { (BEPS-CI2004 } \\
- \text { BEPS-NI2004) }\end{array}$ & $\begin{array}{r}(\text { BEPS-CI2005 } \\
-\quad \text { BEPS-NI2005) }\end{array}$ & $\begin{array}{l}\text { (BEPS-CI2006 } \\
\text { - BEPS- } \\
\text { NI2006) }\end{array}$ & $\begin{array}{l}\text { (BEPS- } \\
\text { CI2007 } \\
\text { - BEPS- } \\
\text { NI2007) }\end{array}$ \\
\hline Oil \& Energy & OIE & 9 & 40.00 & 71.44 & 51.44 & 59.78 \\
\hline Basic Materials & BSM & 25 & 44.88 & 41.28 & 44.36 & 43.92 \\
\hline Consumer Goods & CSG & 22 & 38.14 & 40.77 & 41.27 & 52.11 \\
\hline Consumer Services & CSS & 12 & 44.54 & 48.83 & 44.58 & 35.08 \\
\hline $\begin{array}{c}\text { Financials \& } \\
\text { Real Estate }\end{array}$ & FIR & 19 & 66.08 & 47.89 & 53.11 & 40.68 \\
\hline $\begin{array}{c}\text { Technology and } \\
\text { Telecommunications }\end{array}$ & TET & 5 & 33.40 & 42.00 & 50.80 & 60.30 \\
\hline Total & & 92 & & & & \\
\hline
\end{tabular}

Source: authors' calculations, based on the database and SPSS v.17.0.

Table 9

Kruskal-Wallis Test Statistics in the comparison of Basic Earnings per Share calculated according to Comprehensive Income (BEPS-CI) and Basic Earnings per Share determined pursuant to Net Income (BEPS-NI), by industries, for each of the years in the period 2004-2007, for Spanish groups listed on the Madrid Stock Exchange

\begin{tabular}{|c|c|c|c|c|}
\hline & $\begin{array}{c}\text { (BEPS-CI2004 } \\
\text { - BEPS-NI2004) }\end{array}$ & $\begin{array}{c}\text { (BEPS-CI2005 } \\
- \text { BEPS-NI2005) }\end{array}$ & $\begin{array}{c}\text { (BEPS-CI2006 } \\
- \text { BEPS-NI2006) }\end{array}$ & $\begin{array}{c}\text { (BEPS-CI2007 } \\
\text { BEPS-NI2007) }\end{array}$ \\
\hline Chi-Square & 14.374 & 10.151 & 2.671 & 7.879 \\
\hline df & 5 & 5 & 5 & 5 \\
\hline Asymp. Sig. & 0.013 & 0.071 & 0.751 & 0.163 \\
\hline
\end{tabular}

Source: authors' calculations, based on the database and SPSS v.17.0.

\section{Table 10}

Ranks of Mann-Whitney U Test Statistics in the comparison of Basic Earnings per Share calculated according to Comprehensive Income (BEPS-CI) and Basic Earnings per Share determined pursuant to Net Income (BEPS-NI), by industries, for the year 2004 for Spanish groups listed on the Madrid Stock Exchange [Comparisons for the variable (BEPS-CI - BEPS-NI) for the year 2004 of the Financial \& Real Estate industry as opposed to the rest of industries, except Oil \& Energy]

\begin{tabular}{|c|c|c|c|}
\hline INDUSTRY & N & Mean Rank & Sum of Ranks \\
\hline Basic Materials (BSM) & 25 & 18.08 & 452.00 \\
\hline Financials \& Real Estate (FIR) & 19 & 28.32 & 538.00 \\
\hline Total & 44 & & 333.00 \\
\hline Consumer Goods (CSG) & 22 & 15.14 & 528.00 \\
\hline Financials \& Real Estate (FIR) & 19 & 27.79 & 133.50 \\
\hline Total & 41 & & 362.50 \\
\hline Consumer Services (CSS) & 12 & 11.13 & \\
\hline Financials \& Real Estate (FIR) & 19 & & 27.08 \\
\hline Total & 31 & 5.40 & \\
\hline Technology \& Telecommunications (TET) & 5 & 14.37 & 273.00 \\
\hline Financials \& Real Estate (FIR) & 19 & & \\
\hline Total & 24 & & \\
\hline
\end{tabular}

Source: authors' calculations, based on the database and SPSS v.17.0. 
Table 11

Mann-Whitney U Test Statistics in the comparison of Basic Earnings per Share calculated according to Comprehensive Income (BEPS-CI) and Basic Earnings per Share determined pursuant to Net Income (BEPS-NI), by industries, for the year 2004, for Spanish groups listed on the Madrid Stock Exchange

[Significant test for the variable (BEPS-CI - BEPS-NI) for the year 2004 of the Financial \& Real Estate industry as opposed to the rest of industries, except Oil \& Energy]

\begin{tabular}{|c|c|c|c|c|}
\hline & BSM / FIR & CSG / FIR & CSS / FIR & TET / FIR \\
\hline Mann-Whitney U & 127.00 & 80.00 & 55.50 & 12.00 \\
\hline Wilcoxon W & 452.00 & 333.00 & 133.50 & 27.00 \\
\hline Z & -2.64 & -3.41 & -2.38 & -2.53 \\
\hline Asymp. Sig. (2-tailed) & 0.008 & 0.001 & 0.017 & 0.011 \\
\hline Exact Sig. [2*(1-tailed Sig.] & & & 0.016 (a) & 0.009 (a) \\
\hline
\end{tabular}

(a) Not corrected for ties.

Source: authors' calculations, based on the database and SPSS v.17.0.

In short, for the period and sample studied, we have shown a picture in which, except for the year 2004 just analyzed, far from what could have been predicted by the noticeable differences between industries given by the descriptive statistics, also influenced by the extreme values and outliers, the impact of Basic Earnings per Share calculated according to Comprehensive Income (BEPS-CI) and Basic Earnings per Share determined in accordance with Net Income hardly shows significant differences. This means that we have a phenomenon which in general similarly affects different companies, independently of the nature of the activities that they carry out.

\section{CONCLUSIONS}

We have undertaken empirical evaluation of the overall impact, and by industries, of Basic Earnings per Share calculated according to Comprehensive Income and Basic Earnings per Share determined in accordance with Net Income for a sampling of 92 Spanish groups listed on the Madrid Stock Exchange in the period 2004-2007, both disclosed pursuant to the IASB GAAP.

We have demonstrated that there are statistically significant differences between both ratios for the sample set when applying the Wilcoxon Signed-Ranks Test.

However, when the study was itemized by industries, applying as a priori tests the Kurskal-Wallis Test and the Median Test, and as post hoc tests the Mann-Whitney U Test and the Kolmogorov-Smirnov Test, significant differences are registered only for the year 2004, and for a very small number of pairs of industries over the total of sixty possible comparisons.

Consequently, this empirical evidence allows to affirm that we have a material or statistically significant impact of Basic Earnings per Share calculated according to Comprehensive Income on Basic Earnings per Share determined in accordance with Net Income. But when the analysis is specified by industries, we have a phenomenon which, in general, similarly affects corporate groups, independently of the nature of the activities they carry out.

In this way, still taking into consideration the limitations of the ratios created with accounting information, such as those studied, the results of our research open the door to a new perspective for the analysis of the earnings of economic entities. This new perspective involves the consideration of the new elements that Comprehensive Income introduces in companies earnings against the most traditional Net Income, mainly of interest to analysts and investors.

Likewise, our work can represent a contribution to the debate generated within the Presentation of Financial Statements project, jointly developed by the IASB and the FASB, given that based on the statistical evidence contributed when carrying out the study for the sample set, the inclusion in the notes of the Basic Earnings per Share determined according to Comprehensive Income is not only justified, but also its revelation in the main body of the Statement of Comprehensive Income is included in a much more prominent or important way. 


\section{AUTHOR INFORMATION}

F. Sousa Fernández. PhD. Associate Professor of Financial Economy and Accounting at the University of Cantabria (Spain). Doctoral Thesis: Comprehensive Income in the Context of International Financial Information: Conceptual Framework, Comparative Analysis on Standards and an Empirical Research for European Groups Listed in NYSE and NASDAQ. He has published a great number of articles on Comprehensive Income in Scientific and Professionals Reviews, including one published in the International Business \& Economics Research Journal (Clute Institute), and another one accepted for publication in the same journal. He has won several awards for articles derived from research in Comprehensive Income, granted by the most prestigious Associations and Organizations in the field of Accounting and Business Administration in Spain, such as AECA, ICAC, ASEPUC and CEF.

$\mathbf{M}^{\mathbf{a}}$ Mercedes Carro Arana. PhD. Assistant Professor and Vice Dean in Business Administration at the University of Cantabria (Spain). She is also Legal Practicing Auditor. Doctoral Thesis: The Auditor in the Insolvency Procedures (Conceptual Framework and Empirical Research). She is Author of Different Articles in Scientific and Professionals Reviews, including one accepted for publication in the International Business \& Economics Research Journal (Clute Institute), and Papers in National Congresses (AECA, ASEPUC, ICAC) and International: European Accounting Association -EAA-, Iberian-American of Finances and Systems of Information -FSI-, Assian-Pacific Conference on International Accounting Issues -APA-. She has directed research for MBA and other investigation projects on topics related with Audit, International Accounting and Insolvency Procedures.

\section{REFERENCES}

1. Beale, B. and Davey, H., The Nature and Origins of Comprehensive Income, in S. B. Dahiya (ed.), The Current State of Business Disciplines, SpellBound Publications Ltd., New Delhi, Vol. 1, pp. 81-100, 2000.

2. Bhamornsiri, S. and Wiggins, C., Comprehensive Income Disclosures, The CPA Journal, October, pp. 5456, 2001.

3. Bolsa de Madrid, Listed Companies on Madrid Stock Exchange and Industry Classification, available in http://www.bolsademadrid.es [accessed on December, 2007 and December, 2008].

4. $\quad$ Brief, R. P. and Peasnell, K. V., Clean Surplus: A link Between Accounting and Finance, Garland Publishing, Inc., New York and London, 1996.

5. Comisión Nacional del Mercado de Valores, CNMV, Consolidated Financial Statements of Spanish Companies listed on the Madrid Stock Exchange, available in http://www.cnmv.es [accessed on November and December, 2008].

6. Dhaliwal, D.; Subramanyam, K. R., and Trezevant, R., Is Comprehensive Income superior to Net Income as a measure of firm performance, Journal of Accounting and Economics, Vol. 26, pp. 43-67, 1999.

7. Feltham, G. A. and Ohlson, J. A., Valuation and Clean Surplus Accounting for Operating and Financial Activities, Contemporary Accounting Research, Vol. 12, Spring, pp. 689-731, 1995.

8. Financial Accounting Standards Board, FASB, SFAC 6, Elements of Financial Statements (a replacement of FASB Concepts Statements 3 -incorporating an amendment of FASB Concepts Statement No.2-), 1985, available in http:///www.fasb.org [accessed on November 14, 2008].

9. Financial Accounting Standards Board, FASB, SFAS 130, Reporting Comprehensive Income, 1997, available in http:///www.fasb.org [accessed on November 14, 2008].

10. Financial Accounting Standards Board, FASB, Financial Statement Presentation, Joint Project of the IASB and the FASB, Memorandum of Understanding -MoU-, 2009, available in http://www.fasb.org [accessed on March, 2009].

11. Hirst, D. E., and Hopkins, P. E., Comprehensive Income Reporting and Analysts' Valuation Judgements, Journal of Accounting Research, Vol. 36, Supplement, pp. 47- 75, 1998.

12. Hodder, L. D.; Hopkins, P. E., and Wahlen, J. M., Risk-Relevance of Fair-Value Income Measures for Commercial Banks, The Accounting Review, Vol. 81, nº 2, pp. 337-375, 2006.

13. Hunton, J. E.; Libby, R., and Mazza, C. L., Financial Reporting Transparency and Earnings Management, The Accounting Review, Vol. 81, no 1, pp. 135-157, 2006.

14. International Accounting Standards Board, IASB, IAS 1, Presentation of Financial Statements, in Improvement to International Accounting Standard, (revised in 2007), London, 2003. 
15. International Accounting Standards Board, IASB, IAS 33, Earnings per Share, in International Financial Reporting Standards: Bond Volume, 2008, IASB-IASC, London, 2003.

16. International Accounting Standards Board, IASB, IAS 1, Presentation of Financial Statements, in International Financial Reporting Standards: Bond Volume, 2008, IASB-IASC, London, 2007.

17. International Accounting Standards Board, IASB, Financial Statement Presentation, Joint Project of the IASB and the FASB, Memorandum of Understanding -MoU-, 2009, available in http://www.iasb.org [accessed on March, 2009].

18. Linsmeier, T.J.; Gribble, J.; Jennings, R.G.; Lang, M.H.; Penman, S.H.; Petroni, K.R.; Shores, D.; Smith, J.H. and Warfield, T.D., An Issues Paper on Comprehensive Income, American Accounting Association's Financial Accounting Standards Committee, Accounting Horizons, Vol.11, nº 2, p. 120-126, 1997.

19. Luecke, W. and Meeting, D. T, How Companies Report Income, Journal of Accountancy, May, pp. 45-52, 1998.

20. Maines, L. A. and McDaniel, L. S, Effects of Comprehensive-Income Characteristics on Nonprofessional Investors' Judgements: The Role of Financial-Statement Presentation Format, The Accounting Review, Vol. 75, No. 2, pp. 179-207, 2000.

21. Mattessich, R., The Theory of Clean Surplus and Its Evolution: Survey and Recent Perspectives, EnergeiaRevista Internacional de Filosofía y Epistemología de las Ciencias Económicas, Vol. 1, nº 2, Universidad de Ciencias Empresariales y Sociales, Buenos Aires, invited paper (with Spanish text translation on pp. 4979), pp. 9-79, 2002.

22. O'Hanlon, J. F. and Pope, P. F., The Value-Relevance of UK Dirty Surplus Accounting Flows, British Accounting Review, Vol. 31, pp. 459-482, 1999.

23. Pandit, G. M.; Rubenfield, A. and Phillips, J. J., Current NASDAQ Corporation Methods of Reporting Comprehensive Income, Mid - American Journal of Business, Spring, Vol. 21, nº 1. pp. 13-19, 2006.

24. Siegel, S. and Castellan, N. Jr., Non Parametric Statistics for the Behavioral Sciences, MacGraw-Hill International Sciences, Second Edition, International Edition, 1988.

25. Sousa Fernández, F., Comprehensive Income in the Context of International Financial Information: Conceptual Framework, Comparative Analysis on Standards and an Empirical Research for European Groups Listed in NYSE and NASDAQ [on line], Doctoral Thesis, University of Cantabria (Spain), Department of Business Administration, 2007, http://www.tesisenred.net/TDR-0430108-085640, [accessed on March, 2009].

26. Statistical Package for the Social Sciences, SPSS Inc., SPSS Software, v. 17.0, 2008.

\section{NOTES}

1 In order to delve into further detail on the conceptual background of comprehensive income, or on an equivalent approach provided by clean surplus, the following, among others, may be consulted: Feltham and Ohlson (1995), Brief and Peasnell (1996), Linsmeier et al., AAA (1997), Beale and Davey (2000), Mattessich (2002) and Sousa (2007).

2 The CNMV is responsible for the supervision, monitoring and control of the Spanish Stock Exchanges.

3 Likewise, since values are taken repeatedly for the same subjects during the years of the period 2004-2007, a repeated measures ANOVA model may also be used, using as within-subjects factor the year and as between-subjects factor the sector.

4 The extreme values are cases with values of more than 3 box lengths from the upper or lower edge of the box, taking into consideration that its length is the interquartile range; the outliers correspond to cases with values between 1.5 and 3 box lengths from the upper or lower edge of the box, with the length of the box also being the interquartile range. 
NOTES 